UDC 613.955

DOI: $10.21668 /$ health.risk/2020.2.05.eng

\title{
HYGIENIC OPTIMIZATION OF EDUCATIONAL PROCESS AT SCHOOL INVOLVING MASSIVE USE OF ELECTRONIC LEARNING DEVICES
}

\author{
I.E. Aleksandrova \\ National Medical Research Center for Children's, 2 Bld., 1 Lomonosovskii Ave., Moscow, 119991, Russian Federation
}

\begin{abstract}
Active use of electronic learning devices (ELD) in educational process increases its efficiency and makes knowledge more available to children; but at the same time it creates risks for schoolchildren's health. Intense visual and information loads can result in schoolchildren being over-exhausted.

Our research goal was to give scientific grounds for hygienic optimization of education process (a typical class and a schedule) that would allow preventing apparent exhaustion in schoolchildren studying in a digital environment.

To solve the fixed tasks, we applied hygienic, physiological and statistical research techniques. We analyzed factors occurring in school environment and components in education process structure; we examined parameters of body functional state (BFS) on a sampling made up of more than 600 schoolchildren attending 5-9 ${ }^{\text {th }}$ grades, namely, parameters that characterized their mental and visual working abilities.

Results were statistically processed with parametric and non-parametric analysis techniques. Relative risks of unfavorable outcomes in body functional state were calculated as per evidence-based medicine principles depending on how education process was organized (a structure of a class and classes schedules).

We developed methodical approaches to hygienically rational organization of a class and schedule provided that school environment was optimal (microclimate, luminance, electromagnetic fields, furniture in rooms, etc.) and electronic learning devices were applied according to age-related regulations.

Research results proved that implementation of suggested approaches would make for favorable dynamics of children's functional state as well as prevention of education-related diseases.

Key words: schoolchildren, digital environment, over-exhaustion, hygienic optimization, class, schedule, body functional state, prevention of education-related diseases.
\end{abstract}

In a hyper-information society, one of the most important tasks is to preserve health of the younger generation. Digital environment has a serious impact on behavior, lifestyle and forms additional risk factors for the health of children and adolescents $[1,2]$. There is an increase in information load and psychoemotional overexertion, growth of information dependence in various forms [3-5], an increase in the prevalence of borderline mental and behavioral disorders in children and adolescents [6]. The extended use of the Internet by children is associated with a decrease in verbal intelligence and brain development disorders in the area responsible for speech, attention, emotions, etc. [7]. A significant number of publications' authors relating to digital media impact on health characterize their use by nowadays children and adolescents as excessive, which is seen as the main factor that can hinder the formation of a «healthy psychophysiological tolerance» [8-12].

At the same time, the main and most noticeable trend in current education is primarily associated with the increasing use of digital tools in educating children and adolescents. Having huge opportunities that increase the education efficiency, studying within digital environment forms a complex of factors that have a potentially negative effect on schoolchildren health. These factors include an increased visual load, intensification of learning work, increased static tension and hypokinesia $[13,14]$.

In recent years, the impact of the most common ELDs (personal computer, laptop, interactive whiteboard, tablet) on schoolchildren's BFS has been studied [15-18]. The works showed that the unregulated use of ELDs in educational process causes deteriora-

(C) Aleksandrova I.E., 2020

Irina E. Aleksandrova - Doctor of Medical Sciences, Chief researcher at the Laboratory for complex problems of children and teenagers hygiene (e-mail: accialex@yandex.ru; tel.: +7 (495) 917-10-60; ORCID: https://orcid.org/0000-0002-8664-1866). 
tion of general physical and mental condition, decrease in visual, mental working capacity of students, impossibility to keep optimum visual distance; makes for formation of a «forward» working posture in a student.

As a result of analyzing changes in functional state of students' bodies in a lesson dynamics, based on different time-periods of ELDs using, the tolerable duration for their use was determined, exceeding which the significant negative dynamics of BFS indicators was detected. In the course of this research, regulations were established for safe use of: computer, interactive board and laptop at lessons, escalatory influence of ELDs on educational activity and student's BFS is shown provided their rational, in terms of hygiene, application $[17,18]$. Positive effect was expressed, first of all, in emotional activation of central nervous system, optimization of visual analyzer function, increasing level of mental working abilities of a student.

Using electronic devices changes the tedium of a lesson for students. Research was carried out to identify factors that determine exhaustion from a current lesson in school. It was established that the multi-component concept of a lesson' tedium includes: difficulty of an educational subject, student's abilities and inclinations, conditions of education. The difficulty scales of educational subjects were justified to organize educational schedules for 1-9 grade students and its hygienic assessment [19].

Teachers themselves, assessing positively the effect of current digital lessons on schoolchildren development, also noted the increase in informational load, intensification of learning activities [20, 21].

The emergence of new risk factors for the development and health of students who are almost permanently in a «digital school» environment necessitates their comprehensive study. Along with the inter-school environment conditions (including physical parameters of ELDs themselves, their placement, regulations for operation, etc.) and the duration of e-Learning tools using, it is necessary to assess, in terms of hy- giene, the organization of a current learning process: architecture of a school lesson, a schedule. Only this approach will give an opportunity to take into account and minimize the eventual health risks for schoolchildren.

The goal of the present research was to give the scientific grounds for hygienic optimization of educational process to prevent an apparent exhaustion in schoolchildren studying in the conditions of digital environment.

To achieve this goal, the following tasks were solved:

- to study the relationship between BFS indicators of students and indicators characterizing the organization of a lesson;

- to study the effect of preventive actions at a lesson with ELDs on indicators of mental and visual working abilities;

- to justify hygienic assessment technique for a lesson;

- to study the correlation of students BFS indicators with the "hygienic rationality» of a lesson schedule.

Data and methods. We applied a complex of hygienic, physiological, and also statistical methods of research.

In conditions of using ELDs for lessons, we assessed factors of school environment and BFS parameters of 607 students in 5-9 grades. The research was based on the study of mental working abilities (MWA), which is an overall indicator of BFS in children ${ }^{1}$. MWA is of crucial importance for learning activities. MWA was assessed based on the results of the corrective test - a time-proportioned technique which allows for obtaining information about the major parameters that characterize mental performance: quantity of works performed and quantity of errors made. The ratio of these parameters determines the work productivity, and it is given a comprehensive assessment («excellent», «good», «satisfactory», «bad», «unsatisfactory»). Based on the sum ratio of «excellent» and «good» marks to the sum of «bad» and 'unsatisfactory' ones, an overall indicator of a class working ability is calculated.

\footnotetext{
${ }^{1}$ Unified Methodology for Hygienic Study of Organizing the Conditions and Regime of Computer-Assisted Educational Classes: Methodical Recommendations (in Russian). In: G.N. Serdyukovskaya ed. Moscow, 1987, 91 p. (in Russian).
} 
Functional state of the central nervous system in dynamics was assessed taking into account the nature of individual changes in working abilities from the beginning to the end of a lesson. To analyze the effect of a teaching process' organization on schoolchildren's MWA, we chose the most «unfavorable» variations in changes reflecting the apparent and expressed exhaustion, when there was a decrease (preservation) in the number of characters viewed at the same (the increasing) number of errors, or a decrease in the number of viewed characters at increasing errors.

In a school day dynamics, the MWA indicators of 211 schoolchildren attending 5-9 grades with different lessons organization (varying density of a lesson, varying number of learning activities) and drawing-up an educational schedule (at different compliance with hygienic recommendations) were evaluated.

We assessed MWA indicators in 396 secondary school students (grades 5-9) depending on the presence (or absence) of a set of preventive measures (ophthalmic exercises and physical activity) during class. In addition, visual exhaustion indicators were studied in this group of children. We used methods to determine critical flicker fusion frequency (CFFF), accommodation amplitude and fatigue level of ciliary muscle. CFFF study technique is designed to determine the lability of visual analyzer cortical link, which, if decreasing, is evidenced by a decrease in the frequency of individual light flickers differentiation that allows talking of visual fatigue of a student. Accommodation amplitude characterizes the change in eye optical power during accommodation, and the fatigue level of the ciliary eye muscle is characterized by the fatigue factor the percentage ratio of the difference between accommodation amplitudes at the beginning and at the end of observation to the initial accommodation amplitude. A negative value of the fatigue factor indicates an increase in accommodation amplitude, while a positive one speaks for its decrease.
In order to identify the nature and duration of various learning activities in a lesson, we used a stop-watch study. The stop-watch study in organization of 32 lessons was carried out. We estimated the lesson density (the lesson amount of time spent on learning activity to the total lesson time, in percentage), the number of changes of learning activity types.

The educational schedule was analyzed using the «Electronic methodical complex for hygienic assessment of school schedule» ${ }^{2}$ created by the authors based on the new scales of difficulty for academic subjects, designed with reference to the current application of ELDs in lessons. Fifteen options for daily schedules and five options for weekly school timeschedules were assessed. The hygienic rationality in drawing up a schedule was determined, first of all, by correspondence of the dynamics of educational subjects' difficulty during a school day (week) to the physiological «curve» of schoolchildren's MWA [22-24].

The results were statistically processed using parametric and non-parametric analysis techniques. Following the principles of evidence-based medicine, we determined the values of relative risk - the probability of «unfavorable» BFS indicators in students depending on the educational environment (lesson construction, educational schedule), which, along with hygienically inefficient organization, become the «risk factors». The number of «unfavorable» BFSs occurred was correlated with the lessons of different density $(70 \%$ and below: over $70 \% ; 80 \%$ and below: over $80 \%$; $90 \%$ and below: over $90 \%$ ), and the varying number of changes in educational activities (5 and below: more than 5; 6 and below: more than $6 ; 7$ and below: more than 7), as well as with studying against the school schedule drawn up with the different rationality (rational - irrational), from the point of hygiene. So, for example, the lesson density of over $90 \%$ means «risk factor available», and the lesson density of $90 \%$ and below - «risk factor absent», the number of schoolchildren with

\footnotetext{
${ }^{2}$ Aleksandrova I.E., Stepanova M.I., Kurganskiy A.M. Electronic Methodical Complex for Hygienic Assessment of School Schedule. Object of intellectual property, database: Certificate No. 2017621265 of 01.11.2017. Bulletin No. 11-2017 (in Russian).
} 
an «unfavorable» type of BFS by the end of the lesson means «outcome present», schoolchildren with no «unfavorable» type of BFS by the end of the lesson means «no outcome», etc.

This way the 4-blocks table of conjugation was filled in (Table 1).

Table 1

Conjunction table

\begin{tabular}{|l|c|c|c|}
\hline Indicator & $\begin{array}{c}\text { Outcome } \\
\text { present (1) }\end{array}$ & $\begin{array}{c}\text { No out- } \\
\text { come (0) }\end{array}$ & In-Total \\
\hline $\begin{array}{l}\text { Risk factor } \\
\text { available (1) }\end{array}$ & $\mathrm{A}$ & $\mathrm{B}$ & $\mathrm{A}+\mathrm{B}$ \\
\hline $\begin{array}{l}\text { Risk factor } \\
\text { absent (0) }\end{array}$ & $\mathrm{C}$ & $\mathrm{D}$ & $\mathrm{C}+\mathrm{D}$ \\
\hline In-Total & $\mathrm{A}+\mathrm{C}$ & $\mathrm{B}+\mathrm{D}$ & $\mathrm{A}+\mathrm{B}+\mathrm{C}+\mathrm{D}$ \\
\hline
\end{tabular}

The value of relative risk was determined by a formula:

$$
\begin{gathered}
R R=(\mathrm{A} /(\mathrm{A}+\mathrm{B})) /(\mathrm{C} /(\mathrm{C}+\mathrm{D}))= \\
=(\mathrm{A} \cdot(\mathrm{C}+\mathrm{D})) /(\mathrm{C} \cdot(\mathrm{A}+\mathrm{B})),
\end{gathered}
$$

where $\mathrm{A}, \mathrm{B}, \mathrm{C}, \mathrm{D}$ are the number of observations in the conjugation table fields. After determining the boundaries of the $95 \%$ confidence interval (not including the unit) we compared the values of relative risk with the unit: we took values over 1 , considering that the factor increases the frequency of outcomes. We calculated: sensitivity $(\mathrm{A} / \mathrm{A}+\mathrm{C} \cdot 100)$ and specificity of methods $\mathrm{D} / \mathrm{B}+\mathrm{D} \cdot 100$. The etiologic factor $(\mathrm{EF})$ for the lesson organization impact on schoolchildren's MWA, which causes an apparent and expressed exhaustion, was determined according to the «evaluation degree of causal connection of health disorders with activities» ${ }^{3}$.

Results and discussion. The classroom conditions, where the research took place, were optimized to the maximum extent possible following the requirements of sanitary regulations. All ELDs used for the lessons had the necessary documentation allowing their use in children's educational institutions.

In the course of analysis, we selected students with «unfavorable» changes in MWA by the end of the lesson, reflecting the development of their apparent and expressed exhaustion.

We determined relative risk $(R R)$ for occurrence of the indicated MWA changes depending on such indicators of the lesson organization as lesson density, educational activity changes frequency (Table 2).

The significant risk of increasing the apparent and expressed exhaustion events in schoolchildren was recorded at the lessons with educational density of over $90 \%$ and with frequency changes in educational activity exceeding 7. In other options of lesson organization, no similar risk was revealed $(R R<1)$.

The etiologic factor of a lesson organization impact on MWA of schoolchildren, which causes an apparent and expressed exhaustion, was described as «high» degree $(57.3 \%)$ - for lesson educational density (above $90 \%$ ) and «average» degree $(41.1 \%)$ - for the frequency of changes in educational activities (above 7), because the duration and consistency of school factors impact on the growing body defines the need to assessing them in a similar way to professional ones.

Table 2

Relative risk of apparent and expressed exhaustion in schoolchildren as a function

\begin{tabular}{|c|c|c|c|c|c|c|}
\hline $\begin{array}{l}\text { BFS indicators } \\
\text { of a student }\end{array}$ & $\begin{array}{c}\text { Lesson organization } \\
\text { indicators }\end{array}$ & $R R$ & $C I^{*}$ & $E F, \%$ & $\mathrm{Se}$ & $S p$ \\
\hline \multirow{2}{*}{$\begin{array}{l}\text { Changes in MWA indicators, } \\
\text { reflecting an apparent and ex- } \\
\text { pressed exhaustion in students }\end{array}$} & Lesson density over $90 \%$ & 3,34 & $2,47-4,49$ & 57,3 & 0,46 & 0,94 \\
\hline & $\begin{array}{c}\text { Over } 7 \text { changes } \\
\text { of educational activity }\end{array}$ & 2,5 & $1,4-3,2$ & 41,1 & 0,96 & 0,37 \\
\hline
\end{tabular}
of lesson organization

N o t e: $* p<0.05 ; R R$ - Relative risk, $C I$ - Confidence interval, $E F-$ Etiologic factor, $S e$ - Sensitivity of method, $S p$ - Specificity of method.

\footnotetext{
${ }^{3}$ Izmerov N.F., Denisov E.I. Occupational Health Risks to Workers: A Guidance. Moscow, 2003, 448 p. (in Russian).
} 
MWA dynamics of students in lessons with and without preventive measures (ophthalmic exercises and physical activity breaks)

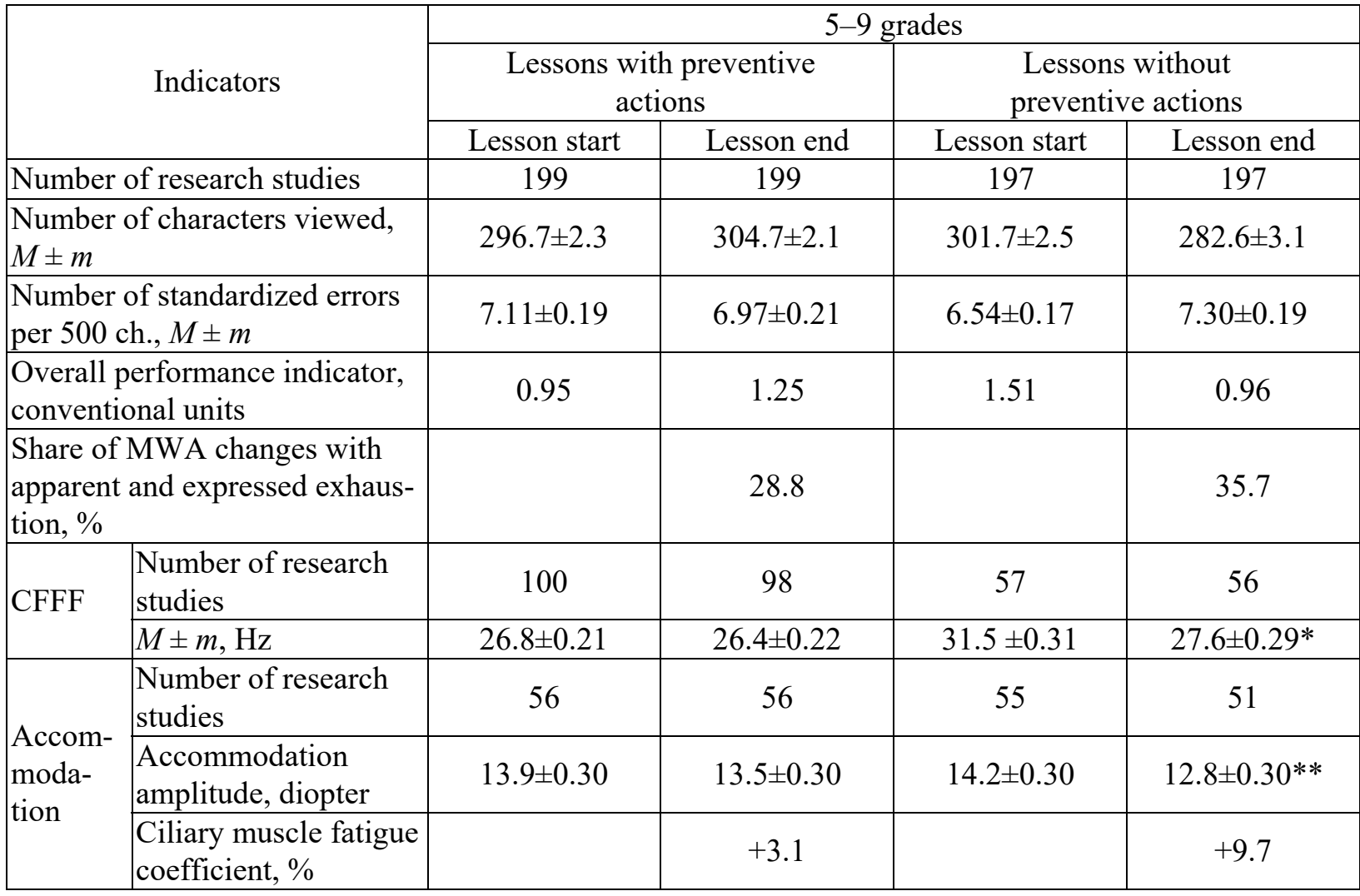

N o t e: $*_{-p}<0.05 ; * *-p<0.01$; MWA - Mental Working Ability, CFFF - Critical Flicker Fusion Frequency.

Also, our research confirmed the effectiveness of preventive activities (ophthalmic exercises and physical activity) in the lessons with using ELDs (Table 3).

After the lessons with the preventive actions taken, the indicators of students' mental and visual working abilities improved. Thus, the overall performance of a class (the sum ratio of «excellent» and «good» marks of MWA to the sum of «bad» and «unsatisfactory» ones) increased by the end of the lesson, which included ophthalmic exercises and physical activity breaks and, on the contrary, decreased in the «control» class. In addition, there was a significant decrease in flicker discrimination frequency in children at the lesson without preventive actions taken (from $31.55 \pm 0.31 \mathrm{~Hz}$ to $27.6 \pm 0.29 \mathrm{~Hz}, p<0.05)$, a decrease in accommodation amplitude and, accordingly, the fatigue rate of ciliary eye muscle.
The data obtained on the dependence of students' BFS on a lesson educational density, frequency of changing the types of teaching activities, availability of preventive measures in a lesson (taking into account the earlier researches outcomes $[12,13]$ to prove regulations for using ELDs in lessons) made it possible to substantiate the hygienic assessment technique for a lesson under conditions of using ELDs.

The technique consists in scoring a lesson by the following parameters:

1. Lesson educational density ( $90 \%$ max);

2. Number of changes in types of educational activity (max 7$)$;

3. Duration of continuous using ELDs (following the age-related regulations);

4. Duration of ELDs using in total (per lesson) (following the age-related regulations);

5. Set of preventive measures available. 
1 point is assigned for each parameter, if hygienic recommendations are met, for noncompliance -0 points. According to the final (total) score of a lesson, the certain level of hygienic rationality was assigned in the following way: hygienically rational lesson: 5 points; insufficiently rational lesson: 3-4 points (herewith each parameter of a lesson no. 1 , no. 3 , no 4 must be evaluated as 1 point); and hygienically irrational lesson: 2 or less points.

This technique for lessons hygienic assessment is recommended to be used both by an educational organization (administration, teachers, medical professionals) for educational process «self-audit» in order to reduce its tedious effect on student body, as well as by specialists of Rospotrebnadzor agencies in the course of surveillance activities.

An important component of the educational process organization is the schedule of lessons.

We assessed the interrelation between an impact of the irrational, from the hygienic point of view, schedule, and the outcomes the number of schoolchildren having changes in MWA reflecting the expressed exhaustion by the end of the school day: significant values of relative risk have been established (Table 4). The etiologic component of the factor - irrationality of the weekly schedule: $53.3 \%$ which was estimated as high correlation between the factor and the outcome. The etiologic component of the factor that reflects the weekly schedule irrationality: $30.7 \%$ was estimated as «average» correlation between the factor and the outcome.

The prevalence of indicators for expressed exhaustion in students increases, when they study against the irrational school schedule (without using an updated «scale of difficulty» for educational subjects created with respect to wide application of ELDs in lessons).

Conclusion. The electronic media widely introduced into current school education causes new health risks for students. The hygienic assessment of «digital» factor of a school environment along with characteristics of an electronic learning device itself, its placement conditions, etc. also entails the analysis of educational process organization: of lesson, of schedules.

The work substantiates optimal, in physiologically-hygienic context, structure of a lesson with using ELDs. We proved the significant risks of increasing the apparent and expressed exhaustion indicators of schoolchildren at the lesson density exceeding $90 \%$ $(R R=3.34)$; at frequency of changes in educational activity of more than $7(R R=2.5)$, and the efficiency of preventive actions at a lesson is confirmed. The proposed technique of a lesson hygienic assessment will allow for timely correction of its organization.

Significant risks of unfavorable changes in mental working ability in the dynamics of education against irrational (without taking

Table 4

Relative risk of expressed exhaustion among students depending on hygienic rationality of school schedule

\begin{tabular}{|c|l|c|c|c|c|c|}
\hline $\begin{array}{c}\text { Student's indicator } \\
\text { of BFS (Outcome) }\end{array}$ & \multicolumn{1}{|c|}{ Educational process factor } & $R R$ & $C I$ & $E F$ & $S e$ & $S p$ \\
\hline $\begin{array}{c}\text { Changes of MWA } \\
\text { indicators reflecting } \\
\text { subjects «difficulty curve» with the } \\
\text { weekly dynamics of mental working } \\
\text { ability }\end{array}$ & $2.13 *$ & $1.04-3.22$ & 30.7 & 0.84 & 0.42 \\
$\begin{array}{c}\text { expressed exhaustion } \\
\text { of students }\end{array}$ & $\begin{array}{l}\text { 2. Non-compliance of the academic } \\
\text { subjects «difficulty curve» with the } \\
\text { daily dynamics of mental working } \\
\text { ability }\end{array}$ & $2.64 *$ & $2.13-3.27$ & 53.3 & 0.29 & 0.96 \\
\hline
\end{tabular}

Note : $-p<0.05 ; R R$ - Relative risk; $C I$ - Confidence interval; $E F$ - Etiologic factor; Se Sensitivity of method, $S p$ - Specificity of method. 
into account the academic subjects difficulty using the updated scales) weekly and daily school schedules (respectively $R R=2.13$ and $R R=2.64)$ were established .

Hygienic optimization of a lesson and a school schedule in the conditions of digital environment, including also the methodical tools proposed for use, will contribute to main- tain favorable dynamics of a students' body functional state and reduce risks of developing an over-exhaustion in process of learning.

Funding. The research was not granted any sponsor support.

Conflict of interests. The authors declare there is no any conflict of interests.

\section{References}

1. Kuchma V.R. Medically-preventive foundations of health safety of pupils over the decade of childhood in Russia (2018-2027). Rossiiskii pediatricheskii zhurnal, 2018, vol. 21, no. 1, pp. 31-37 (in Russian).

2. Kuchma V.R., Sukhareva L.M., Khramtsov P.I. Modern approaches to the support of the hygiene safety of children's life in hyperinformational society. Voprosy shkol'noi $i$ universitetskoi meditsiny $i$ zdorov'ya, 2016, no 3, pp. 22-27 (in Russian).

3. Hoge E., Bickham D., Cantor J. Digital Media, Anxiety, and Depression in Children. Pediatrics, 2017, vol. 140, no. 2, pp. 76-80. DOI: 10.1542/peds.2016-1758G

4. Houghton S., Lawrence D., Hunter S.C., Rosenberg M., Zadow C., Wood L., Shilton T. Reciprocal Relationships between Trajectories of Depressive Symptoms and Screen Media Use during Adolescence. J. Youth Adolesc, 2018, vol. 47, no. 11, pp. 2453-2467. DOI: 10.1007/s10964-018-0901-y

5. Wahyuni A.S., Siahaan F.B., Arfa M., Alona I., Nerdy N. The Relationship between the Duration of Playing Gadget and Mental Emotional State of Elementary School Students. Open Access Maced. J. Med. Sci., 2019, vol. 7, no. 1, pp. 148-151. DOI: 10.3889/oamjms.2019.037

6. Twenge J.M., Joiner T.E., Martin G., Rogers M.L. Digital media may explain a substantial portion of the rise in depressive symptoms among adolescent girls: response to Daly. Clin. Psychol. Sci., 2018, no. 6, pp. 296-297. DOI: $10.1177 / 2167702618759321$

7. Takeuchi H., Taki Y., Asano K., Asano M., Sassa Y., Yokota S., Kotozaki Y., Nouchi R., Kawashima R. Impact of frequency of internet use on development of brain structure and verbal intelligence: longitudinal analyses. Hum. Brain. Mapp., 2018, vol. 39, pp. 4471-4479. DOI: 10.1002/hbm.24286

8. Smahel D., Wright M., Cernikova M. The impact of digital media on health: children's perspectives. Int J. Public. Health, 2015, vol. 60, no. 2, pp. 131-137. DOI: 10.1007/s00038-015-0649-z

9. Körmendi A., Brutóczki Z., Végh B., Székely R. Smartphone use can be addictive? A case report. J. Behav. Addict., 2016, vol. 5, no. 3, pp. 548-552. DOI: 10.1556/2006.5.2016.033

10. Khundadze M., Geladze N., Kapanadze N. Impact of internet gambling on mental and psychological health of children of various ages. Georgian Med. News, 2017, no. 264, pp. 50-53.

11. Lissak G. Adverse physiological and psychological effects of screen time on children and adolescents: Literature review and case study. Environ Res., 2018, vol. 164, pp. 149-157. DOI: 10.1016/j.envres.2018.01.015

12. Singh M. Compulsive Digital Gaming: An Emerging Mental Health Disorder in Children. Indian J. Pediatr, 2019, vol. 86, no. 2, pp. 171-173. DOI: 10.1007/s12098-018-2785-y

13.Lavinskii Kh.Kh., Grekova N.A., Arbuzov I.V., Polyanskaya Yu.N. Riski zdorov'yu detei v «tsifrovoi srede»: puti profilaktiki [Risks for children's health in a «digital environment»: ways to prevent them]. Rossiiskaya gigiena - razvivaya traditsii, ustremlyaemsya v budushchee: materialy XII Vserossiiskogo s"ezda gigienistov i sanitarnykh vrachei. Moscow, 2017, vol. 1, pp. 508-511 (in Russian).

14. Polyanskaya Yu.N., Karpovich N.V., Grekova N.A. Otsenka riska ispol'zovaniya tekhnicheskikh sredstv informatizatsii shkol'nikami [Assessing risks related to use of technical informatization means by schoolchildren]. Chelovek. Zdorov'e. Okruzhayushchaya sreda: sbornik materialov nauchno-prakticheskoi konferentsii s mezhdunarodnym uchastiem. Minsk, 2019, pp. 195-198 (in Russian).

15. Platonova A.G., Yatskovs'ka N.Ya., Dzhurins'ka S.M. Osoblivosti formuvannya robochoi pozi shkolyariv pri roboti z riznimi tipami komp'yuternoi tekhniki [Peculiarities related to formation of a 
working posture when computers are used by schoolchildren]. Gigiena naselenikh mists': Zb. nauk. pr. Kiev, 2014, vol. 63, pp. 255-263 (in Ukrainian).

16. Pol'ka N.S., Platonova A.G., Yatskovs'ka N.Ya. Naukove obrruntuvannya gigiєnichnikh reglamentiv vikoristannya planshetiv ta noutbukiv u shkoli [Scientific substantiation for hygienic standards when laptops and pads are used in schools]. Gigiena naselenikh mists': Zb. nauk. pr. Kiev, 2015, vol. 65, pp. 208-218 (in Ukrainian).

17. Stepanova M.I., Sazanyuk Z. I., Laponova E.D., Voronova B.Z., Lashneva I.P. Justification of regulations for the use of computers with LCD monitor during academic studies. Gigiena i sanitariya, 2014, no. 1, pp. 108-110 (in Russian).

18. Stepanova M.I., Alexandrova I.E., Sazanyuk Z.I., Voronova B.Z., Lashneva I.P., Shumkova T.V., Berezina N.O. Hygienic regulation of the use of electronic educational resources in the modern school. Gigiena $i$ sanitariya, 2015, no. 7, pp. 64-66 (in Russian).

19. Aleksandrova I.E. Optimization of the hygienic assessment of the educational timetable at school. Zdorov'e naseleniya i sreda obitaniya, 2015, vol. 269, no. 8, pp. 24-27 (in Russian).

20.Psikhologo-pedagogicheskie i somaticheskie peremennye $\mathrm{v}$ deyatel'nosti sovremennoi shkoly: effekty kol'tsevoi determinatsii [Psychological-educational and somatic variables in activities performed at a modern school: effects produced by ring determination]. In: S.Yu. Stepanov ed. Moscow, MGPU Publ., 2017, 292 p. (in Russian).

21. Kondakov A.M., Vavilov A.A., Grigoriev S.G., Grishkun V.V. Kontseptsiya sovershenstvovaniya (modernizatsii) edinoi informatsionnoi obrazovatel'noi sredy, obespechivayushchei realizatsiyu natsional'nykh strategii razvitiya Rossiiskoi Federatsii (proekt) [A concept for updating (modernizing) a unified information educational environment that provides implementation of national strategies in the Russian Federation (draft)]. Pedagogika, 2018, no. 4, pp. 98-125 (in Russian).

22. Grombakh S.M. Psikhogigiena uchebnykh zanyatii v shkole [Psychological hygiene of school classes]. Psikhogigiena detei i podrostkov. In: G.N. Serdyukovskaya, G. Gel'nits eds. Moscow, 1985, pp. 92-114 (in Russian).

23. Stepanova M.I. Hygienic assessment of the difficulty of lessons in primary school. Gigiena $i$ sanitariya, 1984, no. 12, pp. 67-69 (in Russian).

24. Grebnyak N.P. Integral assessment of subject difficulties. Gigiena i sanitariya, 2010, no 1, pp. 73-75 (in Russian).

Aleksandrova I.E. Hygienic optimization of educational process at school involving massive use of electronic learning devices. Health Risk Analysis, 2020, no. 2, pp. 47-54. DOI: 10.21668/health.risk/2020.2.05.eng

Received: 13.02 .2020

Accepted: 09.06.2020

Published: 30.06 .2020 